\title{
THE SELF-CONTROLLED AND SELF-RECORDED CLINICAL TRIAL FOR LOW-GRADE MORBIDITY
}

BY

\author{
LANCELOT HOGBEN and M. SIM \\ Birmingham
}

\section{INTRODUCTION}

Medicine has hitherto advanced almost exclusively by study of:

(a) the individual patient in the consulting room, in the clinic, or in the ward;

(b) groups of comparable individuals subjected to different treatments or to different risks.

That we have learned much about controllable agencies contributory to the spread of disease by the group method has long been recognized. That reliance on the clinician's experience of the response of individuals to a particular treatment may lead to unjustifiable conclusions, if without due regard to the principles of controlled experimentation, is also indisputable; and it has lately become a widely accepted dogma that a truly scientific evaluation of the efficacy of therapeutic or prophylactic measures is possible only by recourse to:

(a) recorded responses of treatment and control groups of individuals selected randomwise with or without pairing with reference to putatively relevant variables;

(b) standard statistical tests to validate conclusions referable to comparisons based thereon.

Doubtless the adoption of this discipline has been a salutary check to rash announcements and has promoted a more punctilious regard for rules of evidence. Even so, the claims advanced for it are not beyond the reach of legitimate criticism. The now current recipe for a clinical trial based on group comparison sets out a balance sheet in which individual variability with respect both to nature and to previous nurture does not appear as an explicit item in the final statement of the account; but such variability of response to treatment may be of paramount interest in practice. Partly for this reason, it is difficult to confer any sharp definition on the hypothetical infinite population conceptualized as the source of samples of tested individuals in the theory of any current statistical procedure for validating a comparison. By the same token, it is difficult to specify the precise class of situations to which conclusions endorsed by such procedures are relevant. Nor is it immaterial to mention that the credentials of statistical tests most commonly invoked in this context have lately become the focus of a vigorous controversy which admits no prospect of easy compromise.

In the context of the clinical trial, the word control has all the emotive force of a tradition associated with the advance of physiology to the status of an exact science. This being so, it is fitting to re-examine the disposition to identify controlled experimentation exclusively with group comparison. A little reflection will suffice to discredit the assumption that inquiry limited to successive observations based on a single individual is indeed foreign to the pattern of a rigorously controlled experiment in the biological laboratory. Indeed, a single illustration of a technique which has greatly advanced our understanding of the ductless glands, the control of the circulation, and the mechanism of respiratory movements will make it abundantly clear that exclusive reliance on methods amenable to statistical treatment of groups is inconsistent with laboratory practice universally endorsed since Oliver and Schafer (1894-95) discovered the vasoconstrictor action of extracts of the posterior lobe of the hypophysis and of the adrenal medulla.

Over a wide field of research, the physiologist has long exploited the method of successive differences here called self-controlled experimentation, as in inquiries of the sort last mentioned. A now familiar pattern is as follows:

We prepare an extract from a particular tissue suspected as the seat of production or storage of an active component, we also make extracts $\left(E_{1}, E_{2}, E_{3}\right.$, etc.) of a wide range of other tissues by exactly the same method. We successively introduce in exactly the same way equal quantities of $T$ and of $E_{1}, E_{2}$, etc. into the circulation with equally spaced intervals of recovery in an order which excludes masking an authentic or disclosing 
a spurious effect by reason either of delayed action or of an intrinsic rhythm. Finally, we record the appropriately defined response as + or - . We then say that we have established the seat of the putative active substance if some such record as follows is the outcome:

\begin{tabular}{lllllllllllllll}
\hline $\begin{array}{l}\text { Treatment } \\
\text { Response }\end{array}$ & $\mathrm{E}_{1}$ & $\mathrm{~T}$ & $\mathrm{E}_{2}$ & $\mathrm{~T}$ & $\mathrm{E}_{1}$ & $\mathrm{~T}$ & $\mathrm{E}_{3}$ & $\mathrm{E}_{4}$ & $\mathrm{~T}$ & $\mathrm{~T}$ & $\mathrm{E}_{5}$ & $\mathrm{~T}$ & $\mathrm{E}_{2}$ \\
$\begin{array}{l}\text { Treatment } \\
\text { Response }\end{array}$ & $\mathrm{E}_{1}$ & $\mathrm{E}_{6}$ & $\mathrm{~T}$ & $\mathrm{E}_{5}$ & $\mathrm{~T}$ & $\mathrm{~T}$ & $\mathrm{~T}$ & $\mathrm{E}_{3}$ & $\mathrm{~T}$ & $\mathrm{E}_{6}$ & $\mathrm{~T}$ & $\mathrm{~T}$ & $\mathrm{E}_{4}$ \\
\hline
\end{tabular}

One-to-one correspondence of stimulus and response is here the criterion of a conclusive outcome, and statistical assessment in the current sense of the term is not relevant to its interpretation. What is essentially relevant is the precise specification of all the precautions requisite to correct interpretation, e.g. washing the last remnants from the syringe and attached vein into the circulation by immediate injection of an exactly equal quantity of saline after the injection of each extract. Needless to say, the word exactly in this context is shorthand for as nearly as possible with punctilious regard for every conceivably relevant circumstance. Thus we must concede that the background knowledge, character, and training of the investigator are themselves relevant to our confidence in the validity of the final interpretation; but this caveat has no particular bearing on the thesis that statistical methods are essential to validification of conclusions drawn from experiment. It is indeed a mischievous delusion that statistical recipes can remedy incompetent observation. What sufficiently commends the self-controlled experiment, so interpreted without the nihil obstat et imprimatur of the statistician, is that firmly established conclusions separately referable to individuals with observable peculiarities can provide more refined data for evaluating the role of nature and of previous nurture in the characteristic response to a treatment.

To affirm the possibility of self-controlled experimentation on human subjects is by no means the statement of a new notion. Indeed, one recalls many well-thumbed records of discoveries made by individual investigators who have played the guinea-pig role in their own researches; but there is a pardonable disposition to regard unrecognized motivations of the investigator at work on his own person as inimical to the proper precautions on which the method relies. This misgiving is wholly justifiable, if the recorded response is not amenable to independent observation, as was true in its time of the work of Head, Rivers, and others (1920) on recovery of sensibility during regeneration following nerve section. On the other hand, self-experiment by no means circumscribes the conduct of self-controlled experimentation. This we realize at once, when we recall now sufficiently familiar war-time studies on inanition carried out with the co-operation of ? Quaker volunteers. What justifies the foregoing excursus is that there is still a disposition to regard the method itself with suspicion, to undervalue its merits, to exaggerate the obstacles to employing it or to understate the range of situations in which no such obstacles exist.

If we approach the problem against a background $\approx$ in which the major advances of medicine occurred $\overrightarrow{0}$ in the social setting of pestilences, practical difficul- $\vec{\overrightarrow{ }}$ ties of enlisting volunteers without violence to $\tilde{\sigma}$ ethical standards are easy to exaggerate; but $a \underset{\infty}{\circ}$ wholesome regard for the sanctity of life becomes $\stackrel{\bigcirc}{?}$ increasingly less relevant to a statement of the $v$ priorities of medicine in western communities with a life-expectation well above 60 years at birth. There $\overrightarrow{\mathscr{C}}$ is indeed an ever more pressing need for knowledge $\mathrm{O}$ about many once-thought minor evils. We cannot $工$ effectively tackle them by group methods; but we might well do so with the help of individuals now willing to risk life or limb on the speedway or in the $\frac{0}{0}$ ascent of Mount Everest, if we could institutionalize $\stackrel{\mathbb{}}{-}$ a not uncommon appetite for adventure consistegt $\vec{\varphi}$ with acceptable moral standards. It is not beyote the reach of social engineering to create a new corps if civil defence with that end in view. The voluntasy response to the appeal for blood donors disposes of doubts about the feasibility of such an undertaking, if sponsored by an adequately accredited organization.

Doubts concerning the reliability of evidence obtained by the method of self-controlled experimen- 3 tation on human subjects call for serious consideration in so far as:

(a) we may need to rely on the testimony of the subject for the recording of the relevant response;

(b) both the response per se and the reliability of the record may be influenced by stimuli which operate at a cognitive and/or emotive level.

Each of these considerations calls for directives $>$ more explicit than the proper conduct of animal experiment demands. To forestall misinterpretation $N$ arising from the subject's knowledge of the aim and $\mathrm{N}$ the subject's recognition of the pattern of the trial, it will not suffice to keep the subject in ignorance of the order of presentation of stimuli. In a prolonged $\bar{\sigma}$ trial-and such trials will commonly continue overe a long period-any regularity of the pattern may $\mathbb{D}$ provide clues to recognition. Thus the order of $\stackrel{+}{+}$ presentation must be intrinsically chaotic; and the $\frac{T}{0}$ 
method of presentation must provide the subject with no lead to the identification of the stimulus. Concerning the order, there seems to be no particular reason to adopt the device of attaching random numbers to the stimuli (e.g. tablets), as we should deem to be desirable in the proper domain of stochastic inference. On the contrary, intentional disorder, i.e. a pattern assigned to make easier the recognition of delayed action and to forestall misinterpretation of a normal rhythm would appear to be a more reliable way of achieving the end in view.

As regards concealment of more explicit clues, the following procedure is commendable:

(i) the physician-investigator supervises the allocation of code numbers or letters to the stimuli for presentation in the pre-assigned order;

(ii) an intermediary (e.g. nurse, orderly, houseman) equipped with the code signs and the programme of presentation has no knowledge of the code;

(iii) the subject who receives the stimulus from the intermediary does so without access to the code sign.

These indications do not suffice to dispose of all spurious regularities emergent at the level of cognition. It is pertinent to cite them as prior desiderata because realizable with little inconvenience, if recognized at the outset as such. If surmountable, the special difficulties which beset reliance on the subject's testimony to the appropriate content of the record and the subject's reliable rendition of same also brings into focus the too-little recognized merit of self-controlled experimentation in a field as yet little influenced by the austere regimen of the statistical method. We shall recognize it more clearly, if we are able to sidestep a misgiving which the physician may entertain, if unduly subservient to laboratory tradition. The laboratory worker is suspicious of reliance on verbal testimony, and rightly so if we fail to distinguish between statements of fact accessible to independent observation and statements of feeling not susceptible to independent inquiry. If we reject all verbal testimony for this reason, we shall impose a heavy burden on the physician-investigator. Accordingly, the time-consumption involved in keeping any single subject under observation for a long period will substantially compromise the claims of the method.

The procedure cited above as a type specimen of self-controlled experimentation on laboratory animals is self-recorded in so far as the kymographic signal set-up can incorporate all relevant observations. In so far as it is practicable to prescribe a regimen to ensure reliable and adequate data from a suitably designed document completed by the human subject, we may speak of it as self-recorded and self-controlled experimentation. If such a prescription is indeed practicable, it will be possible to undertake a comprehensive programme of research in hitherto neglected fields of low-grade morbidity by enlisting volunteer subjects in a normal environment without recourse to expenditure on living accommodation. In what follows we shall accordingly assume that:

(i) constant observation of the subject by the investigator is impracticable in the conduct of many worthwhile inquiries;

(ii) the patient's verbal responses constitute a worthwhile source of relevant information if rightly recorded and rightly interpreted;

(iii) our knowledge of referred pain suffices to make real the distinction between right recording and right interpreting without enlisting the reader as a partisan of an explicitly behaviourist outlook.

To get the highest measure of useful and usable co-operation from the subject at the level of reliable recording is the less interesting but not less essential part of our task. For this purpose, it will be necessary to design a daily record sheet:

(a) explicitly specifying all information required to be supplied by subject;

(b) explicitly indicating the time of day at which each item of information is required to be completed;

(c) set out in a form to ensure minimum effort in subsequent analysis by the investigator;

(d) expressed in terms carefully chosen to forestall any error in interpreting the intention with due regard to the intelligence and educational level of the subject.

(e) providing both internal and external means of checking the intrinsic value of the information recorded.

Needless to say, the choice of subjects will determine the scope of the testimony appropriately incorporated in the record. To the extent that it is possible to design records in conformity with these requirements, and more especially with the last, we shall open a new door to psychiatric investigation conducted in terms consistent with the more exacting standards of laboratory experiment on animals. The need to distinguish between internal and external checks on verbal testimony arises from two different levels at which it may be useful, and emphasizes the need for a more refined distinction than the traditional dichotomy of signs and symptoms. If the subject's testimony relates to events 
which any other person would describe in the same terms, the record of his or her own verbal responses is directly assessable by external checks, and the mere fact that it is a statement about himself or herself (e.g. frequency of micturition) does not set it in a category apart from other observations. Another class of assertions relative to the self are not selfmade observations in the commonly accepted sense of the term, i.e. in so far as the meaningful content is manifest at its face value; but the investigation of their consistent relation to the subject's past experience, bodily states, current environment in general, or treatment in particular, may lead to an interpretation which confers on them a hitherto unsuspectedly meaningful content, as the study of referred pain testifies.

For lack of a current term, we may speak of a verbal response of the second sort as non-observational. Though the interpretation may have little or no connexion with the manifest form of words, any regular association between external occurrences or observable bodily states and a verbal response at the non-observational level so defined may well be in its own right an intrinsically valuable addition to our knowledge of human behaviour. Regardless of its ostensible bearing on the end in view, it is therefore desirable that the record should incorporate as much observational testimony amenable to direct observation, and hence to external checking, as is consistent with limitations imposed by the educational level of the subject. This is indeed desirable both because it will provide additional data for validifying the reliability of the record, and because it will offer a background for comparison of non-observational verbal responses and overt behaviour of the sort loosely referred to as discharge of normal bodily functions. It is also desirable, but not always, for another reason. In some inquiries it may suffice for the end in view, if the identification of the treatment procedure does not emerge at the level of cognition. In others it may also be essential to keep the subject in ignorance of the intention, and it will be less easy to accomplish this, if the items of the proforma are exclusively relevant thereto.

Among data for the background picture of the subject's discharge of normal bodily functions and assessment of the subject's reliability as a clerical assistant in the investigation, times of defecation and micturition, body weight, times of retiring and rising, hours of work and physical exertions, are appropriate items of the self-record for subjects of any educational level. After brief preliminary tuition, there is no reason why intelligent volunteers with a good high school record should not also undertake to complete at suitably prescribed intervals entries for pulse and respiration rates, body temperature, and blood pressure.

If we are able to codify a satisfactory regimen of self-recorded testimony for self-recorded and selfcontrolled experimentation so conceived, we have also the means of interpreting regularities of non-observational verbal behaviour with vastly greater economy of effort than the task would otherwise demand. Where it is possible to enlist groups of two or more individuals in cohabitation, we can accommodate synchronization of the record of A's verbal response to his condition with B's verbal description of A's behaviour and vice versa. In this way it may be possible to establish a one-toone correspondence between verbal response at the non-observational level and verbal response at the observational level. In so far as this is indeed possible, it will place at the disposal of the psychiatrist a dictionary of fact and feeling prerequisite to the installation of psychiatry as a branch of experimental medicine.

\section{The Subject}

In what follows, it is not our intention to exhibit the outcome of a self-controlled and self-recorde trial as a contribution to therapeutics. The intention is methodological. Our main concern is to exhib产 the defects of an experiment undertaken without due $\vec{e}$ consideration to design as a basis for prescribing a better procedure. None the less, a few preliminary remarks on the condition of the subject himself are pertinent.

Over a period of about 15 years, the subject had experienced thyroid disorder. Ten years before the experiment began he had undergone partial thyroidectomy for an extensive retrosternal goitre, and nine years later had a second operation for removal of a small median growth of thyroid tissue near the normal site of the isthmus. He had been complaining of increasing lassitude resulting in reduction of his customary activity; but physical investigations provided no grounds for attributing this to previous surgical treatment. His previous retrosternal goitre had been labelled as functional until he himself persuaded a surgeon to explore the affected area. Accordingly, he was not readily disposed to regard his current symptoms as functional. In view of his declared weakness of muscles of articulation and of the legs, his colleague advised the exploration of the possibility that he was suffering from a myopathy such as myasthenia gravis. Since cases of the latter commonly respond to prostigmine, the subject agreed to test its action on himself. 


\section{THE INTENTION}

What began as an academic discussion of the psychological difficulties which may confront the thyroidectomized subject, if previously accustomed to long hours of intense intellectual work and with little capacity for relaxation of mental activity, thus encompassed both the possibility that the subject's condition might be in large measure attributable to involutional phenomena not directly connected with surgical treatment and the possibility that the subject $(\mathrm{H})$ had a myopathy which might respond to prostigmine. It was the former consideration which led the investigator (S) to include in the treatment schedule both a placebo and $d$-amphetamine, but without the subject's knowledge before the completion of the trial.

It would be untrue to say that the writers were fully alert to all the issues stated in the foregoing introductory remarks when they undertook the experiment which follows. Nor would it be true to say that their intention was exclusively directed to evaluate a treatment, to throw light on a pathological condition, or (still less) to explore the usefulness of a particular method of inquiry. The truth is that the motives of each were mixed. In different measure each had some concern for the subject's health and some for the possibility of refining the type of procedure best described as treatment under investigation. The fact that one of the participants, the subject, had a special interest in the design of medical records and that each of them recognized at the outset the pitfalls which beset interpretation of a trial when the yardstick of efficacy is, in part, the affective testimony of the subject did, however, lead at the outset to the adoption of a regimen from the outcome of which they believe it to be possible to infer some useful indications concerning the proper conduct of the self-controlled and self-recorded trial.

Indeed, initial lack of premeditation with that end in view and inadequacy of preliminary planning as seen in retrospect have made them more alert to appropriate safeguards. Thus it goes without saying that the experiment recorded is not a model for others to follow. On the contrary, defects of design, as they came into focus pari passu, are the raw materials from which, as the writers hope, it is now possible to prescribe a more exacting regimen which may prove to be of great value.

\section{Procedure}

In so far as the undertaking had an aim, its aim was to ascertain whether physical fatigue and muscular weakness of which the subject complained was attributable to myasthenia sensu stricto. Thus the subject was aware that the experiment would entail the administration of prostigmine and a control substance, not necessarily inert. He was not aware that his colleage had included in the schedule of treatment courses both a placebo (lactose) and an active reagent (d-amphetamine). The self-record of his reaction to the latter is therefore an internal check on the reliability of the subject's testimony. To keep him wholly in ignorance both of the expected outcome of the treatment administered on any particular day and of the identity of the treatment administered on consecutive days, his colleague prescribed the channel of transmission as follows:

(1) The investigator (S) specified the daily regimen of dosage in conformity with a key identifying that of three consecutive days by a letter of the alphabet.

(2) The liaison officer, a colleague (C), transmitted the daily dosage to the patient in accordance with instructions referable to the code signs only, having therefore no means of inferring whether treatments on successive 3-day periods of a 26-fold sequence were identical, or of identifying the treatment on any single day.

(3) The subject $(\mathrm{H})$ received the dosage from (C) without access to the code sign referable thereto.

Each dose ( 3 times daily) was a tablet of the same size to be swallowed with water. Thus the subject's only means of associating the experience of particular days with a particular treatment was the taste and/or texture of the tablet, if noticed. The subject reported no impression of such differences; and we may here discount this source of leakage. Ideally, it is easy to forestall in a comparable situation by recourse to a standard gelatine capsule.

As stated, the temporal unit of treatment by any one of the three substances administered was 3 days, on each of which the subject received three doses at 4-hourly intervals, the single doses being $5 \mathrm{mg}$. for amphetamine and $15 \mathrm{mg}$. for prostigmine. The experiment went on for $78(=32 \times 6)$ days covering the complete alphabetic code, the actual sequence of 3-day courses being: L. A. L. P. L. A. P. A. L. P. A. L. P. L. L. A. P. L. P. A. P. A. P. A. L. L. Thus the patient received the control agent ten times, prostigmine eight times, and amphetamine eight times. The intercalation of the control in parts of the cycle once or twice between the other two in succession or between successive administration of either is one safeguard against the danger of misinterpreting delayed action. In addition, the comparison of response on the first and third day of each 3-day course allows for a check which would not be applicable in an experiment involving 1-day courses only. 
At the start the subject wrote a summary of normal daily routine of diet, motions, sleep, work, and other particulars referable to the immediate period antecedent to the beginning of the experiment and deemed to be relevant to the definition of the baseline reaction to $L$. Thereafter for each day, he completed a report recording his experience relative to the same and his affective reactions on rising, etc. He followed a consistent plan, though without a pro forma schedule, more by habit than by premeditation. Even so, the outcome illustrates forcibly the loss of information entailed by record-keeping in diary form.

The prescribed times for the three daily doses were 8.30 a.m., noon, and 5.30 p.m. The reader will note that the last dose of the day was not administered immediately before retiring. This was intentional on the part of the colleague (S) responsible for the treatment schedule. Late administration might have led the subject to infer that one of the agents was a soporific or the converse; but the diary discloses no comments on the subject's sleep experience other than times of retiring and rising.

\section{INTERPRETATION OF THE RECORD}

The subject relied on his own experience to record his reactions during the course of the trial; and the testimony placed on record is classifiable under ten headings as below. To interpret the testimony recorded in diary form, it will suffice to adopt a 3-point scale:

Base-line Reaction (-) i.e. normal condition of subject immediately before experiment began.

No Reaction Stated (0).

Reinforced (beneficial) Reaction (+).

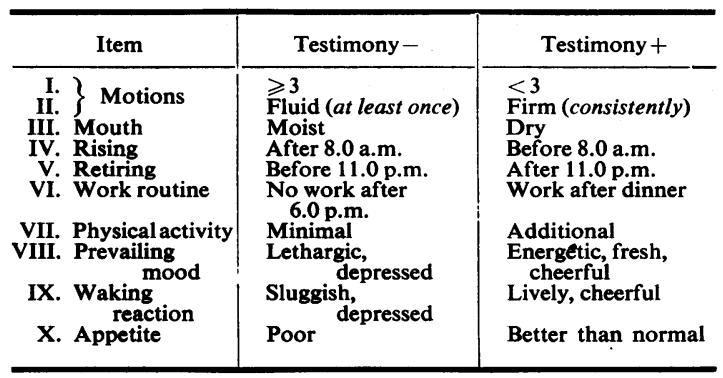

Three items here call for special comment. The subject had recently had denture difficulties associated with buccal dryness and was moreover aware of the fact that one drug administered was prostigmine. The definition of the base-line reaction in Item III is arbitrary, but worth recording because it provides an internal check on testimony value. क The value of Item VII is limited by the fact that there was little occasion to record a positive reaction in the 3 mid-week. Contrariwise, the subject drove 80 miles $\stackrel{\mathbb{Q}}{\circ}$ each way to his country cottage at week-ends when there was opportunity for gardening and walking. $\stackrel{\vec{P}}{+}$ As regards Item $X$, it suffices to say that we deem any favourable comment in the case notes as positive. $\frac{\bar{\sigma}}{\bar{n}}$

We may summarize the outcome in two ways. $\frac{\bar{D}}{\bar{D}}$ First, as in the left hand (unweighted total scores) $\stackrel{\varnothing}{\varnothing}$ columns of Tables I and II (opposite), we may record on how many days the testimony is classifiable $\vec{\circ}$ in terms of each of the three categories (negative, zero, positive) for each treatment. For a 3-day $\vec{\omega}$ course our record might disclose the following picture:

\begin{tabular}{|c|c|c|c|c|c|c|c|c|c|c|}
\hline \multirow{2}{*}{$\begin{array}{c}\text { Day } \\
\text { of } \\
\text { Course }\end{array}$} & \multicolumn{10}{|c|}{ Item } \\
\hline & I & II & III & IV & $\mathbf{V}$ & VI & VII & VIII & IX & $\mathbf{X}$ \\
\hline $\begin{array}{l}1 \\
2 \\
3\end{array}$ & $\begin{array}{r}+ \\
0 \\
-\end{array}$ & $\begin{array}{l}+ \\
+ \\
0\end{array}$ & $\overline{+}$ & $\begin{array}{l}\overline{-} \\
+ \\
+\end{array}$ & $\overline{-}$ & + & $\begin{array}{l}0 \\
0 \\
+\end{array}$ & $\begin{array}{l}- \\
\bar{t}\end{array}$ & $\begin{array}{l}0 \\
0 \\
0\end{array}$ & $\frac{0}{0}$ \\
\hline
\end{tabular}

The score for the single 3-day unit would then be:윰

\begin{tabular}{|c|c|c|c|c|c|c|c|c|c|c|}
\hline \multirow{2}{*}{ Score } & \multicolumn{9}{|c|}{ Item } & \\
\hline & I & II & III & IV & V & VI & VII & VIII & IX & \\
\hline $\begin{array}{l}\overline{\mathbf{0}} \\
+\end{array}$ & $\begin{array}{l}1 \\
1 \\
1\end{array}$ & $\begin{array}{l}0 \\
1 \\
2\end{array}$ & $\begin{array}{l}2 \\
0 \\
1\end{array}$ & $\begin{array}{l}1 \\
0 \\
2\end{array}$ & $\begin{array}{l}2 \\
1 \\
\mathbf{0}\end{array}$ & $\begin{array}{l}1 \\
1 \\
1\end{array}$ & $\begin{array}{l}0 \\
2 \\
1\end{array}$ & $\begin{array}{l}2 \\
0 \\
1\end{array}$ & $\begin{array}{l}\mathbf{0} \\
\mathbf{3} \\
\mathbf{0}\end{array}$ & 0 \\
\hline
\end{tabular}

This method of presentation takes no cognizance $\frac{\circ}{\Phi}$ of a progressive response during the three-day course $\underset{\vec{F}}{\stackrel{2}{*}}$ and outlasting it. One way of doing so employed $\frac{0}{3}$ for the right hand (weighted total scores) columns of Tables I-II is to assign a score of $1,2,3$ to the appropriate testimony on successive days instead of assigning unit scores to each as above. Thus for $11 \mathrm{I} \stackrel{\mathrm{Q}}{\stackrel{\mathrm{O}}{\mathrm{O}}}$ above we shall assign 1 to the first and 3 to the third negative sign and 2 to the single positive one. The 3 . outcome for the single 3-day unit will accordingly be:

\begin{tabular}{|c|c|c|c|c|c|c|c|c|c|c|}
\hline \multirow{2}{*}{ Score } & \multicolumn{10}{|c|}{ Item } \\
\hline & I & II & III & IV & $\mathbf{V}$ & VI & VII & VIII & IX & $\mathbf{X}$ \\
\hline $\begin{array}{l}\overline{0} \\
+\end{array}$ & $\begin{array}{l}1 \\
2 \\
3\end{array}$ & $\begin{array}{l}0 \\
3 \\
3\end{array}$ & $\begin{array}{l}4 \\
0 \\
2\end{array}$ & $\begin{array}{l}1 \\
0 \\
5\end{array}$ & $\begin{array}{l}\mathbf{3} \\
\mathbf{0} \\
\mathbf{3}\end{array}$ & $\begin{array}{l}3 \\
2 \\
1\end{array}$ & $\begin{array}{l}0 \\
0 \\
6\end{array}$ & $\begin{array}{l}\mathbf{3} \\
\mathbf{0} \\
\mathbf{3}\end{array}$ & $\begin{array}{c}0 \\
6 \\
00\end{array}$ & $\begin{array}{l}2 \\
4 \\
0\end{array}$ \\
\hline
\end{tabular}

The alternative methods of presentation adopted were suggested by the subject, the first stage being to complete a schedule specifying for each day of the trial the testimony as negative, zero, or positive for $\frac{}{\Phi}$ each of the ten criteria named. Each of the writers $\stackrel{\oplus}{+}$ felt that his own inclination might prejudice the 
TABLE I

\begin{tabular}{|c|c|c|c|c|c|c|c|}
\hline \multirow{3}{*}{ Item } & \multirow{3}{*}{ Score } & \multicolumn{6}{|c|}{ Total Scores } \\
\hline & & \multicolumn{3}{|c|}{ Unweighted } & \multicolumn{3}{|c|}{ Weighted } \\
\hline & & $\mathbf{L}$ & $\mathbf{P}$ & A & $\mathbf{L}$ & $\mathbf{P}$ & A \\
\hline I & $\begin{array}{l}\overline{0} \\
+\end{array}$ & $\begin{array}{r}1 \cdot 6 \\
20 \cdot 0 \\
2 \cdot 4\end{array}$ & $\begin{array}{r}9 \\
13 \\
2\end{array}$ & $\begin{array}{r}5 \\
17 \\
2\end{array}$ & $\begin{array}{r}3 \cdot 2 \\
40 \cdot 0 \\
4 \cdot 8\end{array}$ & $\begin{array}{r}20 \\
25 \\
3\end{array}$ & $\begin{array}{r}10 \\
33 \\
5\end{array}$ \\
\hline II & $\begin{array}{l}\overline{0} \\
+\end{array}$ & $\begin{array}{r}4 \cdot 0 \\
3 \cdot 2 \\
16 \cdot 8\end{array}$ & $\begin{array}{r}12 \\
4 \\
8\end{array}$ & $\begin{array}{r}5 \\
3 \\
16\end{array}$ & $\begin{array}{r}8 \cdot 8 \\
7 \cdot 2 \\
32 \cdot 0\end{array}$ & $\begin{array}{r}23 \\
8 \\
17\end{array}$ & $\begin{array}{r}10 \\
6 \\
32\end{array}$ \\
\hline III & $\begin{array}{l}- \\
0 \\
+\end{array}$ & $\begin{array}{r}0 \\
20 \cdot 8 \\
3 \cdot 2\end{array}$ & $\begin{array}{r}0 \\
18 \\
6\end{array}$ & $\begin{array}{r}0 \\
19 \\
5\end{array}$ & $\begin{array}{r}0 \\
40 \cdot 8 \\
7 \cdot 2\end{array}$ & $\begin{array}{r}0 \\
36 \\
12\end{array}$ & $\begin{array}{r}0 \\
37 \\
11\end{array}$ \\
\hline IV & $\begin{array}{l}\overline{0} \\
+\end{array}$ & $\begin{array}{r}4 \cdot 8 \\
17 \cdot 6 \\
1 \cdot 6\end{array}$ & $\begin{array}{r}3 \\
18 \\
3\end{array}$ & $\begin{array}{r}2 \\
19 \\
3\end{array}$ & $\begin{array}{r}8 \cdot 8 \\
36 \cdot 8 \\
2 \cdot 4\end{array}$ & $\begin{array}{r}6 \\
35 \\
7\end{array}$ & $\begin{array}{r}5 \\
34 \\
9\end{array}$ \\
\hline V & $\begin{array}{l}\overline{\mathbf{0}} \\
+\end{array}$ & $\begin{array}{l}8 \cdot 0 \\
8 \cdot 0 \\
8 \cdot 0\end{array}$ & $\begin{array}{r}11 \\
5 \\
8\end{array}$ & $\begin{array}{r}4 \\
4 \\
16\end{array}$ & $\begin{array}{l}16 \cdot 0 \\
16 \cdot 0 \\
16 \cdot 0\end{array}$ & $\begin{array}{l}20 \\
11 \\
17\end{array}$ & $\begin{array}{r}10 \\
8 \\
30\end{array}$ \\
\hline VI & $\begin{array}{l}\overline{0} \\
+\end{array}$ & $\begin{array}{r}10 \cdot 4 \\
1.6 \\
12 \cdot 0\end{array}$ & $\begin{array}{r}6 \\
4 \\
14\end{array}$ & $\begin{array}{r}8 \\
1 \\
15\end{array}$ & $\begin{array}{r}19 \cdot 2 \\
4 \cdot 0 \\
24 \cdot 8\end{array}$ & $\begin{array}{r}13 \\
9 \\
26\end{array}$ & $\begin{array}{r}17 \\
2 \\
29\end{array}$ \\
\hline VII & $\begin{array}{l}\overline{0} \\
+\end{array}$ & $\begin{array}{r}4 \cdot 0 \\
10 \cdot 4 \\
9.6\end{array}$ & $\begin{array}{r}4 \\
12 \\
8\end{array}$ & $\begin{array}{r}7 \\
11 \\
6\end{array}$ & $\begin{array}{r}8 \cdot 8 \\
21 \cdot 6 \\
17 \cdot 6\end{array}$ & $\begin{array}{r}8 \\
25 \\
15\end{array}$ & $\begin{array}{l}14 \\
22 \\
12\end{array}$ \\
\hline VIII & $\begin{array}{l}-\overline{0} \\
+\end{array}$ & $\begin{array}{r}2 \cdot 4 \\
19 \cdot 2 \\
2 \cdot 4\end{array}$ & $\begin{array}{r}8 \\
15 \\
1\end{array}$ & $\begin{array}{r}1 \\
15 \\
8\end{array}$ & $\begin{array}{r}4 \cdot 0 \\
40 \cdot 8 \\
3 \cdot 2\end{array}$ & $\begin{array}{r}15 \\
32 \\
1\end{array}$ & $\begin{array}{r}3 \\
29 \\
16\end{array}$ \\
\hline IX & $\begin{array}{l}\overline{0} \\
+\end{array}$ & $\begin{array}{r}0.8 \\
22.4 \\
0.8\end{array}$ & $\begin{array}{r}0 \\
24 \\
0\end{array}$ & $\begin{array}{r}1 \\
19 \\
4\end{array}$ & $\begin{array}{r}2 \cdot 4 \\
43 \cdot 2 \\
2 \cdot 4\end{array}$ & $\begin{array}{r}0 \\
48 \\
0\end{array}$ & $\begin{array}{r}1 \\
35 \\
12\end{array}$ \\
\hline $\mathbf{X}$ & $\begin{array}{l}- \\
0 \\
+\end{array}$ & $\begin{array}{r}2 \cdot 4 \\
15 \cdot 2 \\
6 \cdot 4\end{array}$ & $\begin{array}{r}1 \\
18 \\
5\end{array}$ & $\begin{array}{r}0 \\
21 \\
3\end{array}$ & $\begin{array}{r}4 \cdot 8 \\
28 \cdot 8 \\
14 \cdot 4\end{array}$ & $\begin{array}{r}1 \\
36 \\
11\end{array}$ & $\begin{array}{r}0 \\
41 \\
7\end{array}$ \\
\hline Total & $\begin{array}{l}\overline{0} \\
+\end{array}$ & $\begin{array}{r}38 \cdot 4 \\
138 \cdot 4 \\
63 \cdot 2\end{array}$ & $\begin{array}{r}54 \\
131 \\
55\end{array}$ & $\begin{array}{r}33 \\
129 \\
78\end{array}$ & $\begin{array}{r}76 \cdot 0 \\
279 \cdot 2 \\
124 \cdot 8\end{array}$ & $\begin{array}{l}106 \\
265 \\
109\end{array}$ & $\begin{array}{r}70 \\
247 \\
163\end{array}$ \\
\hline
\end{tabular}

specification at this stage. Accordingly, they delegated it with appropriate instructions to two colleagues*, who devised separate presentations of the results (Tables I and II). The only noteworthy discrepancy refers to Item VII. This is due to the fact that one of the assessors interpreted driving a car in the week-end to the country cottage mentioned above as a positive response, and the other did not do so.

Since the subject received the placebo on 30 days and each of the alternative active agents on 24 days, the scores of the columns marked $L$ in Tables $I$ and II have been adjusted appropriately in the ratio $4: 5$, whence the decimals. Of the two methods of scoring exhibited, we may say that one will disclose a conservative picture of a progressive effect, the other may give undue weight to the terminal day of the course. In so far as the testimony of the two methods points to the same conclusion, as is here true, they reinforce one another.

\footnotetext{
* Our thanks are due to Dr. K.S. Jones of the Department of Clinica Psychiatry, United Birmingham Hospitals, and to Dr. K. W. Cross of the Department of Medical Statistics for undertaking this task.
}

TABLE II

\begin{tabular}{|c|c|c|c|c|c|c|c|}
\hline \multirow{3}{*}{ Item } & \multirow{3}{*}{ Score } & \multicolumn{6}{|c|}{ Total Scores } \\
\hline & & \multicolumn{3}{|c|}{ Unweighted } & \multicolumn{3}{|c|}{ Weighted } \\
\hline & & $\mathrm{L}$ & $\mathbf{P}$ & A & $\mathbf{L}$ & $\mathbf{P}$ & A \\
\hline I & $\begin{array}{l}\overline{0} \\
+\end{array}$ & $\begin{array}{r}2.4 \\
19.2 \\
2.4\end{array}$ & $\begin{array}{r}9 \\
13 \\
2\end{array}$ & $\begin{array}{r}5 \\
16 \\
3\end{array}$ & $\begin{array}{r}4 \cdot 8 \\
38 \cdot 4 \\
4 \cdot 8\end{array}$ & $\begin{array}{r}20 \\
25 \\
3\end{array}$ & $\begin{array}{r}10 \\
32 \\
6\end{array}$ \\
\hline II & $\begin{array}{l}\overline{0} \\
+\end{array}$ & $\begin{array}{r}4 \cdot 8 \\
4 \cdot 8 \\
14.4 \\
\end{array}$ & $\begin{array}{r}12 \\
4 \\
8 \\
\end{array}$ & $\begin{array}{r}5 \\
3 \\
16 \\
\end{array}$ & $\begin{array}{r}9 \cdot 6 \\
11 \cdot 2 \\
27 \cdot 2 \\
\end{array}$ & $\begin{array}{r}23 \\
8 \\
17 \\
\end{array}$ & $\begin{array}{r}10 \\
6 \\
32 \\
\end{array}$ \\
\hline III & $\begin{array}{l}\overline{0} \\
+\end{array}$ & $\begin{array}{r}0 \\
21 \cdot 6 \\
2 \cdot 4\end{array}$ & $\begin{array}{r}0 \\
18 \\
6\end{array}$ & $\begin{array}{r}0 \\
19 \\
5\end{array}$ & $\begin{array}{r}0 \\
43 \cdot 2 \\
4 \cdot 8 \\
\end{array}$ & $\begin{array}{r}0 \\
36 \\
12 \\
\end{array}$ & $\begin{array}{r}0 \\
37 \\
11 \\
\end{array}$ \\
\hline IV & $\begin{array}{l}\overline{0} \\
+\end{array}$ & $\begin{array}{r}4.8 \\
17.6 \\
1.6\end{array}$ & $\begin{array}{r}3 \\
18 \\
3\end{array}$ & $\begin{array}{r}5 \\
16 \\
3\end{array}$ & $\begin{array}{r}8 \cdot 8 \\
36 \cdot 8 \\
2 \cdot 4\end{array}$ & $\begin{array}{r}6 \\
35 \\
7\end{array}$ & $\begin{array}{r}13 \\
26 \\
9\end{array}$ \\
\hline V & $\begin{array}{l}\overline{0} \\
+\end{array}$ & $\begin{array}{l}8 \cdot 0 \\
8 \cdot 0 \\
8 \cdot 0\end{array}$ & $\begin{array}{r}11 \\
5 \\
8\end{array}$ & $\begin{array}{r}4 \\
5 \\
15\end{array}$ & $\begin{array}{l}16.0 \\
16.0 \\
16.0\end{array}$ & $\begin{array}{l}20 \\
11 \\
17\end{array}$ & $\begin{array}{l}10 \\
11 \\
27\end{array}$ \\
\hline VI & $\begin{array}{l}-\overline{0} \\
+\end{array}$ & $\begin{array}{r}6 \cdot 4 \\
2.4 \\
15 \cdot 2 \\
\end{array}$ & $\begin{array}{r}6 \\
1 \\
17 \\
\end{array}$ & $\begin{array}{r}5 \\
2 \\
17\end{array}$ & $\begin{array}{r}12 \cdot 8 \\
4 \cdot 8 \\
30 \cdot 8 \\
\end{array}$ & $\begin{array}{r}14 \\
2 \\
32\end{array}$ & $\begin{array}{r}9 \\
5 \\
34 \\
\end{array}$ \\
\hline VII & $\begin{array}{l}\overline{0} \\
+\end{array}$ & $\begin{array}{r}0 \cdot 8 \\
20 \cdot 8 \\
2 \cdot 4\end{array}$ & $\begin{array}{r}0 \\
15 \\
9\end{array}$ & $\begin{array}{r}1 \\
18 \\
5\end{array}$ & $\begin{array}{r}2 \cdot 4 \\
40 \cdot 8 \\
4 \cdot 8\end{array}$ & $\begin{array}{r}0 \\
31 \\
17\end{array}$ & $\begin{array}{r}1 \\
35 \\
12\end{array}$ \\
\hline VIII & $\begin{array}{l}\overline{0} \\
+\end{array}$ & $\begin{array}{r}2 \cdot 4 \\
19 \cdot 2 \\
2 \cdot 4\end{array}$ & $\begin{array}{r}12 \\
11 \\
1\end{array}$ & $\begin{array}{r}2 \\
14 \\
8\end{array}$ & $\begin{array}{r}4 \cdot 0 \\
40 \cdot 8 \\
3 \cdot 2\end{array}$ & $\begin{array}{r}23 \\
24 \\
1\end{array}$ & $\begin{array}{r}4 \\
28 \\
16\end{array}$ \\
\hline $1 X$ & $\begin{array}{l}\overline{0} \\
+\end{array}$ & $\begin{array}{r}0.8 \\
21.6 \\
1.6\end{array}$ & $\begin{array}{r}0 \\
23 \\
1\end{array}$ & $\begin{array}{r}2 \\
16 \\
6\end{array}$ & $\begin{array}{r}2 \cdot 4 \\
43 \cdot 2 \\
2 \cdot 4\end{array}$ & $\begin{array}{r}0 \\
45 \\
3\end{array}$ & $\begin{array}{r}3 \\
30 \\
15\end{array}$ \\
\hline $\mathbf{x}$ & $\begin{array}{l}\overline{0} \\
+\end{array}$ & $\begin{array}{r}2.4 \\
13 \cdot 6 \\
8.0\end{array}$ & $\begin{array}{r}2 \\
16 \\
6\end{array}$ & $\begin{array}{r}0 \\
19 \\
5\end{array}$ & $\begin{array}{r}4 \cdot 0 \\
28 \cdot 0 \\
16 \cdot 0\end{array}$ & $\begin{array}{r}3 \\
31 \\
14\end{array}$ & $\begin{array}{r}0 \\
38 \\
10\end{array}$ \\
\hline Total & $\begin{array}{l}\overline{0} \\
+\end{array}$ & $\begin{array}{r}32 \cdot 8 \\
148 \cdot 8 \\
58 \cdot 4\end{array}$ & $\begin{array}{r}55 \\
124 \\
61\end{array}$ & $\begin{array}{r}29 \\
128 \\
83\end{array}$ & $\begin{array}{r}64 \cdot 8 \\
303 \cdot 2 \\
112 \cdot 4\end{array}$ & $\begin{array}{l}109 \\
248 \\
123\end{array}$ & $\begin{array}{r}60 \\
248 \\
172\end{array}$ \\
\hline
\end{tabular}

In thus tabulating the scores it is necessary to take cognizance of the fact that Items IV (Time of Rising) and IX (Waking Reaction) refer to reactions antecedent to the stimulus prescribed for the day. Accordingly, we must antedate by one day the score recorded for each. It is for this reason that we cite them in one and the same column (19) for convenience of sorting in the illustrative predesigned proforma below.

\section{Need for Pre-Designed Record}

We need not here discuss in detail the positive outcome of the experiment recorded in the two Tables. The results, such as they are, give no indication of a myasthenia responsive to prostigmine, and the subject's reaction to amphetamine is consistent with what we might expect, if his symptoms were attributable to a functional disorder. Our concern is mainly with the defects which the record reveals. From this viewpoint, the outstanding fact disclosed is the loss of information attributable to 
reliance on a case history recorded in diary form. There is an overall percentage of more than fifty unspecified responses. This illustrates a general principle of documentation more honoured in the breach than in the observance. Conclusive interpretation of medical documents is often impossible, because the observer records an event only if it forces itself on his attention. No record is wholly adequate unless it evokes a decisive answer to every question relevant to the enquiry it subserves.

A record programmed in accordance with this principle with a view to unequivocal instructions for hand or pre-coded mechanical sorting would have set out the ten items extracted from the case history in a daily pro forma as in cols. 17-21 of the illustrative specimen shown in Fig. 1 (opposite). For reasons already stated, it should also accommodate additional information with a view to:

(a) internal checks on the reliability of the subject's testimony;

(b) fruitful comparison of the results of similar experiments on other individuals.

Needless to say, no simple formula embraces the requirements of experiments of this type; but it may be of help to others, if we here proffer a layout which would have ensured a more satisfactory outcome of the experiment recorded in Section 5 above. Our concern with information of the sort specified by (b) above is to seek indications of physical build or case history likely to throw light on why some individuals respond in one way, others in another, to one and the same treatment. To accommodate such information it is desirable to complete separately:

(i) an initial record for rendition by the investigator at the beginning of treatment;

(ii) the daily record for rendition by the subject.

We discuss the layout of $(i)$ in Section 7 below. In Fig. 1 we exhibit illustratively a pattern of the layout of the daily record, preferably for printing on card to facilitate hand sorting. To accommodate additional checks on the reliability of the subject's testimony, it includes several items for which the diary record made no provision.

\section{AsSESSMENT OF INDIVIDUAL VARIATION}

In the introductory remarks of this communication, we have raised the issue: does the assessment of group response to a therapeutic agent by reliance on significance tests or on interval estimation give due weight to relevant information about individual variation contributory to response to treatment? The question is not new. In essence, the pattern of statistical procedure which became fashionable after the publication of Greenwood and Yule (1915) dates from the context of Quetelet's Essai de physique sociale (1835). This doubtless inspired Jules Gavarret's Principes généraux de statistique médicale (1840). Gavarret's plea for the statistical approach evoked little positive response at the time; but we may surmise that it inspired a rejoinder too little quoted of late years. In his lectures (published in English in 1927 as An Introduction to the Study of Experimental Medicine), Claude Bernard (1865) thus expressed the authentic reaction of the experimentalist to statistics conceived in Quetelet's terms as the science of averages:

By destroying the biological character of phenomena, the use of averages in physiology and medicine usually gives only apparent accuracy to the results. From our point of view, we may distinguish between several kinds of averages: physical averages, chemical averages, and physiological and pathological averages. If, for instance, we observe the number of pulsations and the degree of blood pressure by means of the oscillations of a manometer throughout one day, and if we take the average of all our figures to get the true or average blood pressure and to learn the true or average number of pulsations, we shall simply have wrong numbers. In fact, the pulse decreases in number and intensity when we are fasting and increases during digestion or under different influences of movement and rest; all the biological characteristics of the phenomena disappear in the average. Chemical averages are also often used. If we collect a man's urine to analyse the average, we get an analysis of a urine which simply does not exist; for urine, when fasting, is different from urine during digestion. A startling instance of this kind was invented by a physiologist who took urine from a railroad station urinal where people of all nations passed, and who believed he could thus present an analysis of average European urine! Aside from physical and chemical, there are physiological averages, or what we might call average descriptions of phenomena, which are even more false. Let me assume that a physician collects a great many individual observations of a disease and that he makes an average description of symptoms observed in the individual cases; he will thus have a description that will never be matched in nature. So in physiology, we must never make average descriptions of experiments, because the true relations of phenomena disappear in the average; when dealing with complex and variable experiments, we must study their various circumstances, and then present our most perfect experiments as a type, which, however, still stands for true facts. In the cases just considered, averages must therefore be rejected, because they confuse, while aiming to unify, and distort while aiming to simplify. Averages are applicable only to reducing very slightly varying numerical data about clearly defined and absolutely simple cases ... I I acknowledge my inability to understand why results taken from statistics are called laws; for in my opinion 


\section{DAILY RECORD}

Complete items specified by columns 11-12, 19, 23, 24, before breakfast, items specified by 13-14, 23, 24, at 12.30 p.m., items specified by 15-16, 23, 24 at 10.00 p.m., otherwise immediately before retiring.

\section{1-12 PULSE RATE ON WAKING \\ 13-14 PULSE RATE AT 12.30 p.m. \\ 15-16 PULSE RATE AT 10.0 p.m. \\ 17 MOTIONS Insert number}

1-8 SUBJECT'S REGISTRATION No. (Birmingham Code)

9-10 DAY OF TRIAL (the first, second . . 12th, etc. being 01,02 . . 12, etc.)

18 APPETITE Ring appropriate item

(1)


scientific law can be based only on certainty, on absolute determinism, not on probability ... In every science, we must recognize two classes of phenomena; first, those whose cause is already defined; next, those whose cause is still undefined. With phenomena whose cause is defined, statistics have nothing to do; they would even be absurd. As soon as the circumstances of an experiment are well known, we stop gathering statistics: we should not gather cases to learn how often water is made of oxygen and hydrogen; or when cutting the sciatic nerve, to learn how often the muscles to which it leads will be paralysed. The effect will occur always without exception, because the cause of the phenomena is accurately defined ... Certain experimenters, as we shall later see, have published experiments by which they found that the anterior spinal roots are insensitive; other experimenters have published experiments by which they found that the same roots were sensitive. These cases seemed as comparable as possible; here was the same operation done by the same method on the same spinal roots. Should we therefore have counted the positive and negative cases and said: the law is that anterior roots are sensitive, for instance, 25 times out of a 100 ? Or should we have admitted, according to the theory called the law of large numbers, that in an immense number of experiments we should find the roots equally often sensitive and insensitive? Such statistics would be ridiculous, for there is a reason for the roots being insensitive and another reason for their being sensitive; this reason had to be defined; I looked for it, and I found it; so that we can now say: the spinal roots are always sensitive in given conditions, and always insensitive in other equally definite conditions.

Many of our contemporaries will brush aside the claim that scientific law must be based on certainty by citing the principle of uncertainty in electronics; but the use of statistical theory to construct hypotheses which stand or fall by the arbitrament of experiment in no sense conflicts with the view Claude Bernard here asserts. If study of the behaviour of an organism leads us to proffer an average as the outcome of prescribed conditions, we have not as yet established the law of its behaviour. We have done so when, and only when, a more refined prescription of the conditions will ensure a uniform response. How far statistical methods can indeed contribute to the initial stage of an investigation by screening likely clues is not the issue which Claude Bernard raises. In contemporary terms what he rightly rejects is the now widely current practice of publishing as a discovery what is at best an encouragement to further examination.

If the comments of Claude Bernard on the use of averages were salutary in his time, they are still more so in our own context. In Bernard's day, the statistician was content to assert a modest claim to the supervision of interpretation; in ours, he claims the prerogative of prescribing the "Design of Experiments", i.e. the conduct of experiments to supply figures which certain test and estimation procedures can, or purport to be able to, accommodate. Indeed, Cattell and Williams (1953) referring to the use of factor analysis in physiological enquiry, go so far as to say:

Although it is true that any experimental statistical design permits one to look for a law in the relation between certain variables, without entering the experiment with too definite a hypothesis as to what form the law must take, factor analysis is unique in demanding no prior hypothesis and in being automatically productive of a hypothesis. One may start with a highly specific hypothesis about the forms and relations of the factors, but this is not necessary. For a pattern of factor loadings - a cluster of variables-suggests immediately something about the nature of a certain influence behind them. This creates the hypothesis by which one enters the next experiment into which some new variable can now be inserted and which may be designed more explicitly to measure the hypothesized influence. But, in entering the initial factor analytic study, one need not have any more definite a hypothesis than is necessary to choose a set of variables, the relations among which are likely to be of interest, in this case to human physiology.

(Italics inserted)

Though the acceptance of such claims is a repudia? tion of the methods by which the experimenta市 sciences have attained their present status, no experimental scientist of Bernard's standing has hitherto accepted the challenge publicly. It is therefore pertinent to state that the issue is essentially a matter of method on which mathematicians as such have no prior claim to arbitrate. If, as we so often hear, statistics is the science of averages, the statistician has a special claim to our attention when the end in view is to record averages, as is true of demographic studies and administrative inquiries which do not concern themselves with individuals as such; but it is for the biologist and the clinician themselves to decide whether an average can be a satisfactory answer to questions they ask about the individual organism. The statement that solutions of iodine in KI makes starch paste blue in 75士 1.5 per cent. of samples examined will not commend itself to a chemist. He will wish to know what impurities, or what range of $p \mathrm{H}$ values, etc., determine when the reaction does or does not occur. Such has been the attitude in which physiologists have hitherto undertaken the investigation of animal behaviour. If we abandon it, we are lowering our standards and concealing our retreat from a position of hard-won advantage behind an impressive façade of irrelevant algebra. 
To appreciate the full force of the contention cited above, we shall do well to recall the history of the therapeutic trial. The association of stochastic theory with medicine antedates Gavarret by threequarters of a century. About the middle of the 18th century, when the Turkish practice of vaccination had lately come into Western Europe, the statistics of smallpox enlisted the interest of both Jean d'Alembert and Daniel Bernoulli. By a method which can stand on its feet without recourse to the classical theory of probability the latter was able to show how the incidence of a disease which confers immunity must decline as age advances; but the mathematical viewpoint made little headway in medicine till smallpox became an issue for legislative intervention. Indeed, public controversy concerning compulsory immunization in the closing years of the 19 th and in the first few decades of the 20th century sufficiently explains the eagerness to invoke the statistician as arbitrator of the claims of the laboratory and of the layman.

Henceforth, we have been more and more disposed to assume that the problem of the prophylactic and that of the therapeutic trial are formally identical. This identification is admissible only if we lose sight of the end in view. In the practice of preventive medicine our concern is with numbers, and the framework of our problem is essentially one of social accountancy. In the practice of curative medicine our concern is with the sick individual, and reliance on averages as a criterion of preference may lead us to recommendations inconsistent with the end in view.

That this is so will be immediately apparent, if we pause to consider a fictitious situation. We may suppose:

(i) that a Disease $\mathrm{D}$ is incurable if untreated;

(ii) that a clinical trial of the usual type leads us to assess the recovery-rate under Treatment $A$ as about 25 per cent. and the recovery-rate under Treatment $B$ as about 50 per cent.

In such circumstances, we too easily then content ourselves with a recommendation to step up the recovery rate by 25 per cent. by substituting Treatment B for Treatment A. If so, our preoccupation with averages has blinded us to biological realities. Were we alert to the manifold interaction of nature and nurture, the outcome would invite us to ask the question: what peculiarities are common to individuals who respectively respond or fail to respond to one or other treatment?

For heuristic reasons, let us now assume that:

(a) persons with grey or brown eyes invariably respond to Treatment $B$ and fail to respond to Treatment A; (b) persons with blue eyes invariably respond to Treatment A but not to Treatment B;

(c) blue-eyed individuals and individuals with grey or brown eyes occur in the population in the ratio $25: 50$;

(d) our clinical trial groups are representative in the sense that the ratio of blue-eyed persons to persons with grey or brown eyes is also close to $25: 50$.

On these assumptions the recovery rate would be 100 per cent. if all $D$ patients with blue eyes continued to receive Treatment $A$ and all $D$ patients with gray or brown eyes henceforth received Treatment B.

The advantage of the procedure outlined in this communication is that it leaves us free to select for inquiry individuals with characteristics putatively relevant to the fullest use of an alternative procedure, inasmuch as:

(a) clinical experience already suggests what peculiarities of the individual are indicative of favourable prognosis or otherwise;

(b) intelligently comprehensive design of the initial record accommodates a range of variables likely to screen such characteristics, if such there be.

With this end in view, it is not desirable to proscribe the inclusion of a narrative case history of organic and functional disorder in a folder for each subject, though a general pro forma such as the Cornell Medical Index Health Questionnaire has much to commend it. In any event, it is highly desirable to make provision for one or more predesigned and pre-coded documents recording:

(a) physique;

(b) functional state assessed by biochemical and biophysical tests;

(c) personality structure.

Of (c) it suffices to say that the writers are cooperating in an experimental inquiry with reference to validification of appropriate descriptive nomenclature, and that no satisfactory pre-design for the documentation of basic data of interest to the experimental psychiatrist is likely to emerge unless it is possible to reach agreement about the vocabulary of what Woodger (1952) calls the observational record. As regards $(b)$, a prerequisite to the undertaking is the availability of suitable codes; and it suffices to remark that the Birmingham Department of Medical Statistics will shortly publish such codes in an exposition of the system of self-coded documents already on trial in the professorial units of the Birmingham Medical School. For illustrative purposes, we none the less venture to proffer a specimen pro forma for recording anthropometric data in the initial record for rendition by the 
investigator (Figs 2 and 3). The lay-out shown is suitable for the Powers-Samas machinery (65column punch card, accommodating 39 items of information per column).

\section{Summary}

(1) The current prescription for the conduct of the Clinical Trial relies on statistical assessment of the response of treated and untreated individuals chosen randomwise. The credentials of current procedures for statistical validification of the outcome are by no means immune to criticism; but the comparison of treatment groups in terms of averages is open to criticism for other reasons, in particular because the demonstration that one treatment has a higher recovery rate than another encourages us to evade the question: why do some individuals respond or fail to respond to one or other treatment? More explicitly, we may frame the same question as follows: what circumstances of nature or nurture determine whether the individual patient will or will not respond to such and such a treatment? If an answer to this is indeed the goal of inquiry, the outcome of subjecting individuals with some characteristics to Treatment $A$ and others to Treatment B may well prove to be more advantageous than substituting for Treatment $A$ another Treatment $B$ with a higher average recovery rate.

(2) This communication explores the design of a trial which has as its aim to assess the response of a given individual with explicitly specifiable characteristics to alternative treatments in conformity with - the customary conduct of pharmacological inquiry on individual animal subjects. Its aim is to clarify what conditions we must impose on such a trial if it is to conform to the traditional canons of pharmacological experiments, here described as selfcontrolled, and to advance suggestions for recording reliable information in the most economical way. By self-controlled in this context we connote:

(i) the procedure of repeated administration of alternative stimuli to one and the same individual;

(ii) reliance on one-to-one correspondence of stimulus and response to validate our conclusions.

Since all experimental biologists recognize that physiology has advanced conspicuously by recourse to such procedures without reliance on statistical assessment of group averages, the only debatable issues are:

(a) how far it is possible to standardize the conditions of observation in conformity with the customary safeguards imposed on the conduct of a comparable experiment on an animal subject;

(b) whether the effort necessarily expended in doing so limits the usefulness of the recipe to situations in which the investigator has sufficient time and facilities for direct observation of the subject.

(3) As regards 2(a) above, the major desideratum is that the subject should remain ignorant of the sequence of presentation. Where the stimulus is a drug, this is achievable by:

(i) administration of the drug itself in appropriate disguise, e.g. capsule or suppository;

(ii) defining the instructions for the course in terms which disclose no clue to the identity of the stimulus.

The second of these is easy to accomplish if an intermediary transmits the stimulus in accordance with a code to which he or she has no access and the subject receives the dose without disclosure of the code sign.

(4) As regards 2(b) above, it is our submission that it is possible to prescribe a suitable form of daily self-coded record which the subject can com $=8$ plete pari passu with the sequence of presentation. If a self-controlled experiment may thus be also and reliably self-recorded, we can envisage the conduct on a wide front of researches of a type not hitherto undertaken. Desiderata for successful use of this procedure are that the record should:

(a) provide means of checking the reliability of the subject's testimony;

(b) invite verbal responses which are not ambiguous.

Where it is possible to pair off co-habitant subjects, reciprocal comparison of the subject's testimony to his or her own overt behaviour by the co-subject may both provide an additional means of validating the testimony of the record and of clarifying the interpretation of verbal responses relevant to psychiatric diagnosis.

(5) Needless to say this preliminary prescription of a self-controlled and self-recorded trial is referable to low-grade morbidity alone. For acute and dangerous conditions it can offer nothing; but its usefulness is not negligible on that account. As never before, curative medicine has now to take cognizance of the prominent role of the so-called psychosomatic disorders in the day to day work of general practice and of the large field of mental sickness which lies outside existing provisions for institutional care. 


\section{INITIAL INDIVIDUAL RECORD}

(for completion by the investigator or qualified assistant)

PART I. ANTHROPOMETRIC DATA (a) Males

1-8 SUBJECT'S REGISTRATION No. (Birmingham Code)

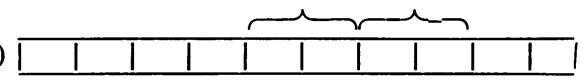

\section{9-12 DATE OF BEGINNING OF TREATMENT}

\section{3-14 STANDING HEIGHT (cm.)}

15-16 SITTING HEIGHT ( $\mathrm{cm}$.

17-18 WEIGHT (lb.)

19-20 MAXIMUM THORACIC CIRCUMFERENCE (cm.) (at nipple line)

21-22 MINIMUM THORACIC CIRCUMFERENCE (cm.) (at nipple line)

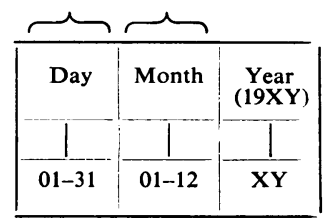

23-24 MAXIMUM TRANSVERSE CHEST DIAMETER ( $\mathrm{cm}$.) (at nipple line)

25-26 MINIMUM TRANSVERSE CHEST DIAMETER ( $\mathrm{cm}$.) (at nipple line)

27-28 ABDOMINAL CIRCUMFERENCE (cm.) (at umbilicus)

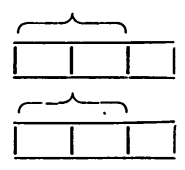

29 COSTAL ANGLE (degrees) AT INSPIRATION

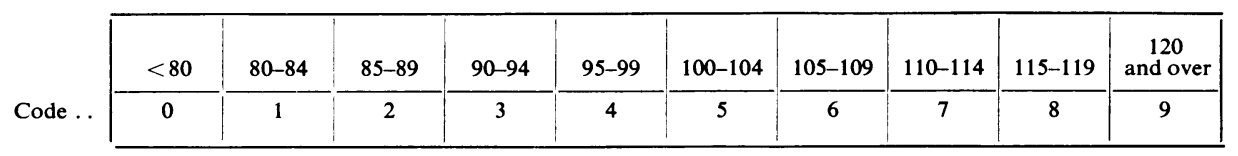

30

COSTAL ANGLE (degrees) AT EXPIRATION

\begin{tabular}{|c|c|c|c|c|c|c|c|c|c|c|}
\hline & $<80$ & $80-84$ & $85-89$ & $90-94$ & $95-99$ & $100-104$ & $105-109$ & $110-114$ & $115-119$ & $\begin{array}{c}120 \\
\text { and over }\end{array}$ \\
\hline Code & 0 & 1 & 2 & 3 & 4 & 5 & 6 & 7 & 8 & 9 \\
\hline
\end{tabular}

31-32 LEG LENGTH (cm.) (ant. sup. iliac spine to tip of lateral malleolus)

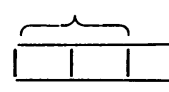

33-34 ARM LENGTH (cm.) (acromion to first carpal crease)

35 HAND LENGTH ( $\mathrm{cm}$.) (first carpal crease to tip of middle finger)

36-37 BISACROMIAL WIDTH OF SHOULDERS (cm.)

38 BICRISTAL PELVIC WIDTH $(\mathrm{cm}$.

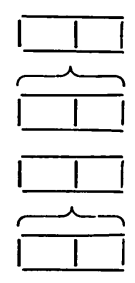

FIG. 2 
PART I. ANTHROPOMETRIC DATA (a) Males-cont.

39 SACRO-PUBIC DEPTH (cm.)

40-41 NECK GIRTH (cm.) (at upper level of thyroid cartilage)

42 MAXIMUM CEPHALIC BREADTH $(\mathrm{cm}$.

- 43 MAXIMUM CEPHALIC LENGTH (cm.)

44-45 MAXIMUM TRUNK LENGTH ( $\mathrm{cm}$.) (suprasternal notch to pubic symphysis)

46-47 MINIMUM TRUNK LENGTH ( $\mathrm{cm}$.) (suprasternal notch to pubic symphysis)

48-49 MEAN (Right-Left) MAXIMUM GIRTH OF CALF (cm.)
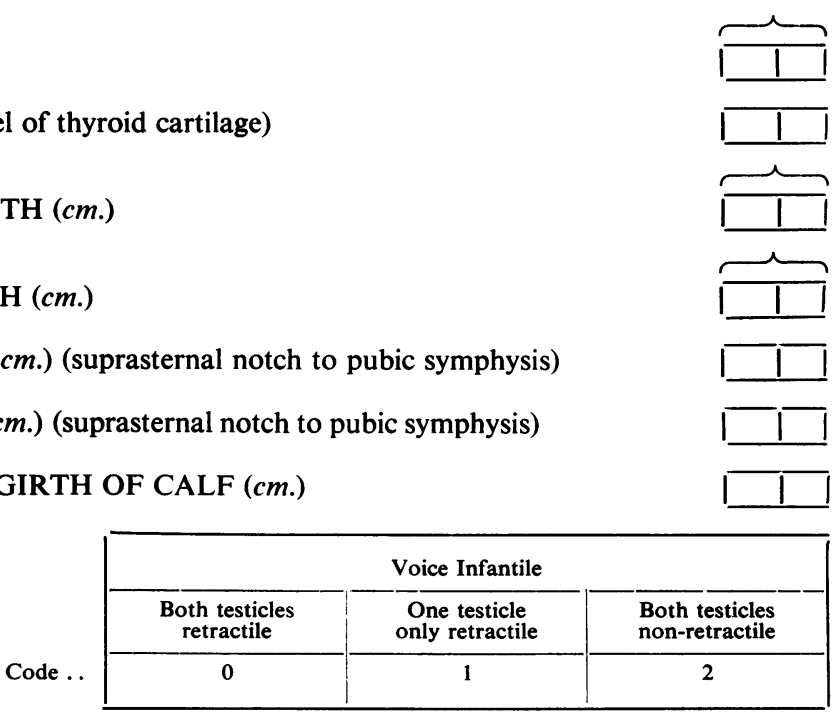

50 SEXUAL DEVELOPMENT

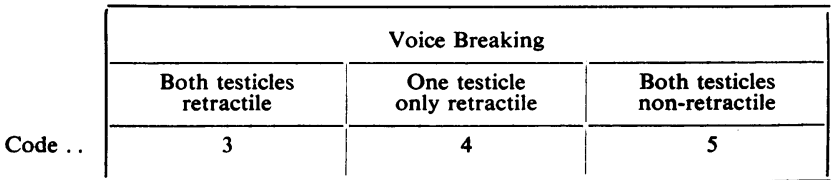

\begin{tabular}{|c|c|c|}
\hline Code .. & \multicolumn{2}{|c|}{ Voice Adult } \\
\hline $\begin{array}{c}\text { Both testicles } \\
\text { retractile }\end{array}$ & $\begin{array}{c}\text { One testicle } \\
\text { only retractile }\end{array}$ & $\begin{array}{c}\text { Both testicles } \\
\text { non-retractile }\end{array}$ \\
\hline 6 & 7 & 8 \\
\hline
\end{tabular}

51 PUBIC-AXILLARY HAIR

\begin{tabular}{|c|c|c|c|c|}
\hline & \multicolumn{2}{|c|}{ Pubic Hair Absent } & \multicolumn{2}{|c|}{ Pubic Hair Present } \\
\hline & $\begin{array}{c}\text { Axillary hair } \\
\text { absent }\end{array}$ & $\begin{array}{l}\text { Axillary hair } \\
\text { present }\end{array}$ & $\begin{array}{c}\text { Axillary hair } \\
\text { absent }\end{array}$ & $\begin{array}{c}\text { Axillary hair } \\
\text { present }\end{array}$ \\
\hline ode & 0 & 1 & 2 & 3 \\
\hline
\end{tabular}

52 HAIR OF SCALP

\begin{tabular}{|c|c|c|c|c|c|c|}
\hline White & Grey & Yellow & Red & $\begin{array}{c}\text { Light } \\
\text { Brown }\end{array}$ & $\begin{array}{c}\text { Dark } \\
\text { Brown }\end{array}$ & Black \\
\hline 1 & 2 & 3 & 4 & 5 & 6 & 7 \\
\hline
\end{tabular}

53 HAIR OF CHIN

\begin{tabular}{|c|c|c|c|c|c|c|}
\hline White & Grey & Yellow & Red & $\begin{array}{c}\text { Light } \\
\text { Brown }\end{array}$ & $\begin{array}{c}\text { Dark } \\
\text { Brown }\end{array}$ & Black \\
\hline 1 & 2 & 3 & 4 & 5 & 6 & 7 \\
\hline
\end{tabular}

54 HAIR OF UPPER LIP

\begin{tabular}{|c|c|c|c|c|c|c|}
\hline White & Grey & Yellow & Red & $\begin{array}{c}\text { Light } \\
\text { Brown }\end{array}$ & $\begin{array}{c}\text { Dark } \\
\text { Brown }\end{array}$ & Black \\
\hline 1 & 2 & 3 & 4 & 5 & 6 & 7 \\
\hline
\end{tabular}

FIG. 2-continued 
PART I. ANTHROPOMETRIC DATA (a) Males-cont.

55 HAIR OF CHEST

\begin{tabular}{|c|c|c|c|c|c|c|}
\hline White & Grey & Yellow & Red & $\begin{array}{c}\text { Light } \\
\text { Brown }\end{array}$ & $\begin{array}{c}\text { Dark } \\
\text { Brown }\end{array}$ & Black \\
\hline 1 & 2 & 3 & 4 & 5 & 6 & 7 \\
\hline
\end{tabular}

56 AXILLARY HAIR

\begin{tabular}{|c|c|c|c|c|c|c|}
\hline White & Grey & Yellow & Red & $\begin{array}{c}\text { Light } \\
\text { Brown }\end{array}$ & $\begin{array}{c}\text { Dark } \\
\text { Brown }\end{array}$ & Black \\
\hline 1 & 2 & 3 & 4 & 5 & 6 & 7 \\
\hline
\end{tabular}

57 PUBIC HAIR

\begin{tabular}{|c|c|c|c|c|c|c|}
\hline White & Grey & Yellow & Red & $\begin{array}{c}\text { Light } \\
\text { Brown }\end{array}$ & $\begin{array}{c}\text { Dark } \\
\text { Brown }\end{array}$ & Black \\
\cline { 1 - 6 } & 2 & 3 & 4 & 5 & 6 & 7 \\
\hline
\end{tabular}

58 EYE COLOUR

\begin{tabular}{|c|c|c|c|c|c|}
\hline Pink & Blue & Grey & Green & Hazel & Dark \\
\hline 1 & 2 & 3 & 4 & 5 & 6 \\
\hline
\end{tabular}

59 ISO-AGGLUTININ GROUP

\begin{tabular}{|c|c|c|c|}
\hline $\mathrm{A}$ & $\mathrm{B}$ & $\mathrm{O}$ & $\mathrm{AB}$ \\
\hline 1 & 2 & 3 & 4 \\
\hline
\end{tabular}

60 RHESUS (D) AND M-N GROUP

\begin{tabular}{|c|c|c|c|c|c|}
\hline \multicolumn{2}{|c|}{$\mathrm{M}$} & \multicolumn{2}{|c|}{$\mathrm{N}$} & \multicolumn{2}{|c|}{$\mathrm{MN}$} \\
\hline $\mathrm{Rh}+$ & $\mathrm{Rh}-$ & $\mathrm{Rh}+$ & $\mathrm{Rh}-$ & $\mathrm{Rh}+$ & $\mathrm{Rh}-$ \\
\hline 1 & 2 & 3 & 4 & 5 & 6 \\
\hline
\end{tabular}

Fig. 2-continued

\section{INITIAL INDIVIDUAL RECORD}

for completion by the investigator or qualified assistant)

PART I. ANTHROPOMETRIC DATA (b) FEMALES

1-8 SUBJECT'S REGISTRATION No. (Birmingham Code)

\begin{tabular}{|l|l|l|l|l|l|l|l|l|}
\hline 1 & 1 & 1 & 1 & & & \\
\hline
\end{tabular}

\section{9-12 DATE OF BEGINNING OF TREATMENT}

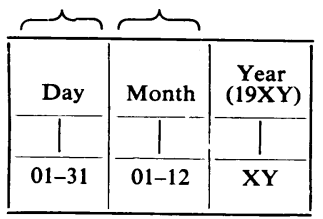

13-14 STANDING HEIGHT $(\mathrm{cm}$.

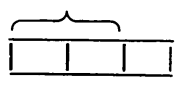

15-16 SITTING HEIGHT $(\mathrm{cm}$.

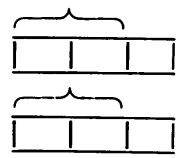

17-18 WEIGHT (lb.) 
PART I. ANTHROPOMETRIC DATA (b) Females-cont.

19-20 MAXIMUM THORACIC CIRCUMFERENCE (cm.) (at nipple line)

21-22 MINIMUM THORACIC CIRCUMFERENCE (cm.) (at nipple line)

23-24 MAXIMUM TRANSVERSE CHEST DIAMETER ( $\mathrm{cm}$.) (at nipple line)

25-26 MINIMUM TRANSVERSE CHEST DIAMETER ( $\mathrm{cm}$.) (at nipple line)

27-28 ABDOMINAL CIRCUMFERENCE (cm.) (at umbilicus)

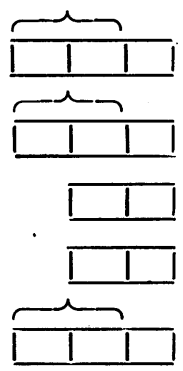

29 COSTAL ANGLE (degrees) AT INSPIRATION

\begin{tabular}{|c|c|c|c|c|c|c|c|c|c|c|}
\hline & $<80$ & $80-84$ & $85-89$ & $90-94$ & $95-99$ & $100-104$ & $105-109$ & $110-114$ & $115-119$ & $\begin{array}{c}120 \\
\text { and over }\end{array}$ \\
\hline Code.. & 0 & 1 & 2 & 3 & 4 & 5 & 6 & 7 & 8 & 9 \\
\hline
\end{tabular}

30 COSTAL ANGLE (degrees) AT EXPIRATION

\begin{tabular}{|c|c|c|c|c|c|c|c|c|c|c|}
\hline & $<80$ & $80-84$ & $85-89$ & $90-94$ & 95-99 & $100-104$ & $105-109$ & $110-114$ & $115-119$ & $\begin{array}{c}120 \\
\text { and over }\end{array}$ \\
\hline Code . & 0 & 1 & 2 & 3 & 4 & 5 & 6 & 7 & 8 & 9 \\
\hline
\end{tabular}

31-32 LEG LENGTH (cm.) (ant. sup. iliac spine to tip of lateral malleolus)

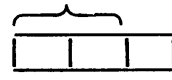

33-34 ARM LENGTH (cm.) (acromion to first carpal crease)

35 HAND LENGTH ( $\mathrm{cm}$.) (first carpal crease to tip of middle finger)

36-37 BISACROMIAL WIDTH OF SHOULDERS (cm.)

38 BICRISTAL PELVIC WIDTH $(\mathrm{cm}$.

39 SACRO-PUBIC DEPTH (cm.)

40-41 NECK GIRTH (cm.) (at upper level of thyroid cartilage)

42 MAXIMUM CEPHALIC BREADTH $(\mathrm{cm}$.

43 MAXIMUM CEPHALIC LENGTH ( $\mathrm{cm}$.)

44-45 MAXIMUM TRUNK LENGTH ( $\mathrm{cm}$.) (suprasternal notch to pubic symphysis)

46-47 MINIMUM TRUNK LENGTH ( $\mathrm{cm}$.) (suprasternal notch to pubic symphysis)

48-49 MEAN (Right-Left) MAXIMUM GIRTH OF CALF (cm.)

50 SEXUAL DEVELOPMENT

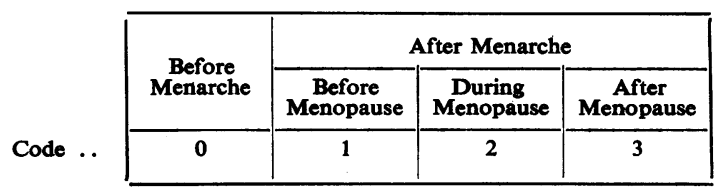

FIG, 3-continued 
PART I. ANTHROPOMETRIC DATA (b) Females-cont.

51 PUBIC-AXILLARY HAIR

\begin{tabular}{|c|c|c|c|}
\hline \multicolumn{2}{|c|}{ Pubic Hair Absent } & \multicolumn{2}{|c|}{ Pubic Hair Present } \\
\hline $\begin{array}{c}\text { Axillary hair } \\
\text { absent }\end{array}$ & $\begin{array}{c}\text { Axillary hair } \\
\text { present }\end{array}$ & $\begin{array}{c}\text { Axillary hair } \\
\text { absent }\end{array}$ & $\begin{array}{l}\text { Axillary hair } \\
\text { present }\end{array}$ \\
\hline 0 & 1 & 2 & 3 \\
\hline
\end{tabular}

52-53 DATE OF 1st DAY OF LAST MENSES BEFORE ADMISSION

54-55 DATE OF 1st DAY OF FIRST MENSES AFTER ADMISSION
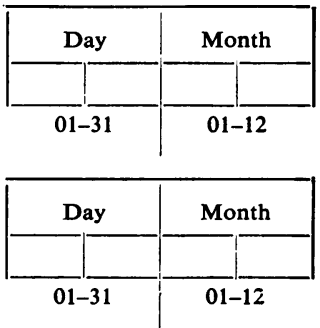

56-57 DATE OF 1st DAY OF SECOND MENSES AFTER ADMISSION

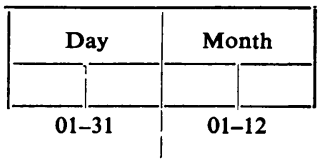

58 HAIR OF SCALP

\begin{tabular}{|c|c|c|c|c|c|c|}
\hline White & Grey & Yellow & Red & $\begin{array}{c}\text { Light } \\
\text { Brown }\end{array}$ & $\begin{array}{c}\text { Dark } \\
\text { Brown }\end{array}$ & Black \\
\hline 1 & 2 & 3 & 4 & 5 & 6 & 7 \\
\hline
\end{tabular}

59 AXILLARY HAIR

\begin{tabular}{|c|c|c|c|c|c|c|}
\hline White & Grey & Yellow & Red & $\begin{array}{c}\text { Light } \\
\text { Brown }\end{array}$ & $\begin{array}{c}\text { Dark } \\
\text { Brown }\end{array}$ & Black \\
\hline 1 & 2 & 3 & 4 & 5 & 6 & 7 \\
\hline
\end{tabular}

60 PUBIC HAIR

\begin{tabular}{|c|c|c|c|c|c|c|}
\hline White & Grey & Yellow & Red & $\begin{array}{c}\text { Light } \\
\text { Brown }\end{array}$ & $\begin{array}{c}\text { Dark } \\
\text { Brown }\end{array}$ & Black \\
\hline 1 & 2 & 3 & 4 & 5 & 6 & 7 \\
\hline
\end{tabular}

61 EYE COLOUR

\begin{tabular}{|c|c|c|c|c|c|}
\hline Pink & Blue & Grey & Green & Hazel & Dark \\
\hline 1 & 2 & 0 & 4 & 5 & 6 \\
\hline
\end{tabular}

62 ISO-AGGLUTININ GROUP

\begin{tabular}{|c|c|c|c|}
\hline $\mathbf{A}$ & $\mathbf{B}$ & $\mathbf{O}$ & $\mathbf{A B}$ \\
\hline 1 & 2 & 3 & 4 \\
\hline
\end{tabular}

63 RHESUS (D) and M-N GROUP

\begin{tabular}{|c|c|c|c|c|c|}
\hline \multicolumn{2}{|c|}{$\mathbf{M}$} & \multicolumn{2}{|c|}{$\mathbf{N}$} & \multicolumn{2}{|c|}{ MN } \\
\hline $\mathbf{R} \mathbf{h}+$ & $\mathbf{R} \mathbf{h}-$ & $\mathbf{R h}+$ & $\mathbf{R h}-$ & $\mathbf{R h}+$ & $\mathbf{R h}-$ \\
\hline 1 & 2 & 3 & 4 & 5 & 6 \\
\hline
\end{tabular}

Fig. 3-continued

REFERENCES

Bernard, C. (1865). "Introduction à l'étude de la médecine expéri- $\quad$ Greenwood, M., and Yule, G. V. (1915). Proc. roy. Soc. Med., 8, 113. mentale". Baillière, Paris. Eng. trans. by H. C. Greene (1927). "An Introduction to the Study of Experimental Medicine". Macmillan, New York.

Cattell, R. B., and Williams, H. F. V. M. (1935). British Journal of Preventive and Social Medicine, 7, 141.

Gavarret, J. (1840). "Principes généraux de statistique médicale". Bechet and Labe, Paris.

Head, H., Rivers, W. H. R., Holmes, G., Sherren, J., Thompson, T., and Riddock, G. (1920). "Studies in Neurology". Oxford University Press, London.

Oliver, G., and Schafer, E. A. (1894-95). J. Physiol., 16, 17, 18.

Quetelet, A. (1835). "Essai de physique sociale". Bachelier, Paris.

Woodger, J. H. (1952). "Biology and Language"; (Tarner Lectures, 1949-50). University Press, Cambridge. 